\title{
"Make Your Own Kind of Music": Queer Student Groups and the First Amendment
}

\author{
Doni Gewirtzman $\dagger$
}

As openly gay and lesbian students become a more regular presence in public high schools, students in many schools have started lesbian and gay student organizations. In response, some school districts and state legislatures have attempted to prevent the clubs from meeting, either through categorical bans on all extracurricular groups or through legislation specifically designed to prevent the gay clubs from meeting. This Comment examines the First Amendment issues raised by these efforts. It argues that the Supreme Court's current approach to student speech, which focuses on whether the speech is school sponsored and on the application of public forum doctrine, lacks an underlying rationale and leads to inconsistent outcomes. In its place, the author urges the Court to adopt a mission-based test that examines the relationship between the regulation on speech and the educational purpose underlying the activity. Because student clubs generally exist to promote self-exploration and foster the development of individual identity, this new test would extend First Amendment protection to gay and lesbian student groups.

Copyright (c) 1998 California Law Review, Inc.

$\dagger \quad$ Skadden Fellow, Lambda Legal Defense and Education Fund; J.D., Boalt Hall School of Law, University of California, Berkeley, 1998; B.A., Wesleyan University, 1993. I thank Robert Post, Rachel Moran, Ruth Harlow, Kate Kendall, Keri Klein, Alison Howard, Sherri Sokeland, Jon Dowell, Machaela Hoctor, and the members of the California Law Review for their invaluable insights, criticism, and encouragement. I could not have done this without them. 


\author{
It may be rough going \\ Just to do your thing's the hardest thing to do \\ But you've got to \\ Make your own kind of music \\ Sing your own special song \\ Make your own kind of music \\ Even if nobody else sings along \\ -Mama Cass ${ }^{1}$
}

\title{
INTRODUCTION
}

In the fall of 1995, Kelli Peterson, a senior at East High School in Salt Lake City, decided to form a gay/straight alliance at her school. ${ }^{2}$ The club was certainly not the country's first ${ }^{3}$ and was one of a number of clubs at the school that focused on issues related to group identity.

The Salt Lake City school district responded to the alliance with immediate hostility. In order to restrict the alliance's ability to meet while complying with the terms of the Equal Access Act, ${ }^{4}$ a federal law constraining the ability of school districts to deny recognition selectively to school-affiliated student organizations, the school board banned all non-curriculum-related clubs from Salt Lake City public schools. ${ }^{5}$ Students, in turn, responded with walkouts and protests against the board's decision, ${ }^{6}$ objecting not to the attack on the queer ${ }^{7}$ student club but to the widespread effects of the ban on other student clubs. ${ }^{8} \mathrm{~A}$ small group of students responded differently, starting a club known as SAFE-Students Against Faggots Everywhere. ${ }^{9}$

1. Mama Cass, Make Your Own Kind of Music, on Music from the Motion Picture Beautiful Thing (MCA Records 1996).

2. See Mark Walsh, Gay Students' Request Spurs Board to Cut Clubs, Educ. Wx., Feb. 28, 1996, at 6.

3. See Kelli Kristine Armstrong, The Silent Minority Within a Minority: Focusing on the Needs of Gay Youth in our Public Schools, 24 Golden GATE U. L. Rev. 67, $89-90$ (1994); Warren J. Blumenfeld, Gay/Straight Alliances: Transforming Pain into Pride, in ThE GAY TEEn: EduCational Practice and Theory for Lesbian, Gay and Bisexual Adolescents 211, 212-13 (Gerald Unks ed., 1995).

4. 20 U.S.C. $\$ \$ 4071-4074$ (1994).

5. See Walsh, supra note 2 , at 6 .

6. See Samuel Autman et al., S.L. Students Rally, Rail and Rebel, SALt LAKE CitY TrIB., Feb. 24, 1996, at A1; Robert Bryson, More than 1,000 Protest Club Ban, Salt LAKE City TrrB., Mar. 3, 1996 , at $\mathrm{Cl}$.

7. I use the word "queer" as an inclusive, nonderogatory term to encompass gay, lesbian, bisexual, and transgendered individuals.

8. See Autman, supra note 6, at A1.

9. See Samuel Autman, Club Ban Sparks Fear, Loathing, ŚALt LAKE City Trub., Feb. 22, 1996, at Al. 
Evidently, the school board's action was not sufficient to satisfy Utah state legislators. Following a closed door meeting, ${ }^{10}$ Utah legislators passed S.B. 1003." After finding that "certain activities, programs, and conduct are ... detrimental to the physical, emotional, psychological, and moral well being of students and faculty," that "local school boards shall deny access to any student organization or club whose program and activities would materially or substantially: (i) cncourage criminal or delinquent conduct; (ii) promote bigotry; (iii) or involve human sexuality." ${ }^{\prime 13}$ A lawsuit against the Salt Lake City school board's actions is underway, ${ }^{14}$ and similar controversies have begun to erupt in other states. ${ }^{15}$

If reviewing courts follow the most recent Supreme Court decision addressing the First Amendment rights of high school students, Hazelwood School District v. Kuhlmeier, ${ }^{16}$ they will likely apply an overly circumscribed analysis that turns on whether or not the speech of the club is "school sponsored."17 If the speech of the clubs is considered school-sponsored speech, courts will subject the state's action to minimal constitutional scrutiny, creating a high likelihood that the ban will survive a constitutional challenge. Alternatively, if the reviewing court finds that the speech is not school sponsored, it will apply a more exacting typc of constitutional rcview that focuses on whether the speech of the clubs would constitute a "material or substantial disruption" to the operation of the school. ${ }^{18}$

This Comment argues that the Court's current approach to student speech issues, which focuses on school sponsorship and public forum doctrine, is fundamentally misguided. By conditioning constitutional protection on facial considerations of sponsorship, the Court has

10. See Dan Harrie \& Judy Fahys, Lanmakers Settle Secret Meeting Suit, Salt LaKe City TruB., Feb. 20, 1997, at A1.

11. UTAH CODE ANN. \$ 53A-3-419 (1996).

12. UTAH CODE ANN. $\$ 53 A-3-419$ (2)(a) (1996).

13. UtAH CODE ANN. $§ 53 A-3-419$ (2)(a)(i)-(iii) (1996) (emphasis added). The statute grants local school boards the authority to determine whether a given club falls within the definition of the law. See UtAH CoDE ANN. \& 53A-3-419 (2)(b) (1996). The Alliance continues to meet without formal school recognition or funding, but it meets after school, when Utah's schools become public forums under a state statute. See Katherine Kapos, Legacy of Utah's Gay-Club Furor; Policy Could Allow Gay Clubs, Salt LaKe City TRIB., Jan. 10, 1997, at DI.

14. See Civil-Rights Groups Sue Over School-Clubs Ban, Salt LaKe City TrRB., Mar. 21, 1998, at Al.

15. See David Olinger, School Gay Rights Group Sues, Denver Post, Jan. 23, 1998, at Cl; Renate Robey, School District to Recognize Gay, Heterosexual Club, DeNVER Post, Feb. 28, 1998, at B1; Arizona Legislators Pattern Gay-Club Ban on Utah Law, SALT LAKE CiTY TRIB., Dec. 25, 1996, at A23; see also Rachel D’Oro, Tempest Brews Over Gay Student Club, ANchorage DalLy News, Nov. 22, 1996, at IB.

16. 484 U.S. 260 (1988).

17. See id. at $270-73$.

18. See Tinker v. Des Moines Indep. Community Sch. Dist, 393 U.S. 503, 509 (1969). 
created a constitutional doctrine that lacks a compelling rationale. I argue that the Court's two stated explanations for focusing on school sponsorship-protecting the school's proprietary interests and minimizing the risk that external observers will attribute student speech to the school-do not adequately explain the broad discretion granted to school authorities. In the process, the doctrine creates unjustifiable inconsistencies between the speech rights of high school and college students.

This Comment suggests that, instead of focusing on sponsorship, the Court should adopt a constitutional test that inquires into the function of educational institutions and ascertains the nature of the relationship between the regulation of speech and the mission of the educational institution. ${ }^{19} \mathrm{~A}$ mission-based test would allow the Court to make principled distinctions among different types of school activities and to ground student speech doctrine in social commitments to First Amendment values and organizational function, considerations that are already present at a subtextual level in prior precedent. While the proliferation of queer student groups inevitably raises constitutional issues related to freedom of association, prior restraint, ${ }^{20}$ state action doctrine, ${ }^{21}$ the relationship between sexuality and the First Amendment, ${ }^{22}$ and statutory questions under the Equal Access $\mathrm{Act}^{23}$ these analyses are beyond the scope of this Comment.

Parts I and II give a history of the Court's major student speech decisions and provide a brief overview of public forum doctrine. Part III examines the Hazelwood decision's use of public forum doctrine and its

19. I derive this suggested approach from the work of Professor Robcrt C. Post. See generally Robert C. Post, Behveen Governance and Management: The History and Theory of the Public Forum, 34 UCLA L. Rev. 1713 (1987) [hereinafter Post, Between Governance and Management]; Robcrt C. Post, Racist Speech, Democracy, and the First Amendment, 32 WM. \& MARY L. Rev. 267 (199I) [hereinafter Post, Racist Speech]; Robert Post, Recuperating First Amendment Doctrine, 47 STAN. L. Rev. 1249 (1995) [hereinafter Post, Recuperating First Amendment Doctrine].

20. See Muller v. Jefferson Lighthouse Sch., 98 F.3d 1530, 1540-41 (7th Cir. 1996) (holding that school policy requiring written permission to distribute non-school-sponsored materials was not an unconstitutional prior restraint on speech).

2I. See, e.g., Yeo v. Town of Lexington, 131 F.3d 241 (1st Cir. 1997) (holding that high school yearbook's decision not to run certain advertisements was not state action).

22. See generally Daniel S. Alter, Confronting the Queer and Present Danger, 22 Hum. RTs. 22 (1995); Nan D. Hunter, Identity, Speech, and Equality, 79 VA. L. REv. 1695 (1993); Brent Hunter Allen, Note, The First Amendment and Homosexual Expression: The Need for an Expanded Interpretation, 47 VAND. L. REv. 1073 (1994).

23. In fact, it is far more likely that litigants will bring challenges to club bans under the Equal Access Act rather than the First Amendment. See, e.g., Hsu v. Roslyn Union Free Sch. Dist. No. 3, 85 F.3d 839 (2d Cir. 1996) (upholding after-school club's Christian officer requirement under the Equal Access Act); Ceniceros v. Board of Trustees of the San Diego Unified Sch. Dist., 66 F.3d 1535 (9th Cir. 1995) (holding that school's refusal to allow student religious club to meet during school period violated the Act); Pope v. East Brunswick Bd. of Educ., 12 F.3d 1244 (3d Cir. 1993) (holding that school's refusal to certify student Bible club violated the Act). 
introduction of sponsorship into First Amendment jurisprudence. Part IV examines how a reviewing court might treat the Utah statute under current doctrine. Part V argues that there is no underlying rationale for using school sponsorship to determine the free speech rights of student clubs, while Part VI argues that the Court should adopt a mission-based rationale instead of focusing on sponsorship. Finally, Part VII applies the suggested mission-based test to student groups, arguing that gay and lesbian student groups are entitled to constitutional protection.

Tinker To Fraser:

\section{The Evolution of Student SpeEch Doctrine}

Before exploring how a reviewing court might approach the dilemma created by Utah's ban, some doctrinal background is necessary to explain the Court's current approach to student speech. The Court's four major cases in the area-Tinker $v$. Des Moines Independent Community School District, ${ }^{24}$ Board of Education v. Pico, ${ }^{25}$ Bethel School District No. 403 v. Fraser, ${ }^{26}$ and Hazelwood-provide a starting point for examining the difficult constitutional issues raised by the creation and continued presence of queer student organizations in public high schools.

The Supreme Court's student speech jurisprudence has developed along three distinct yet highly interrelated paths. First, the Court's discussion about the mission of American education shifted emphasis to stress public education's role in the inculcation of values, ${ }^{27}$ while deemphasizing education's role in fostering independent thought. Second, the Court increased the level of deference accorded to school authorities in their decision to restrict student speech. ${ }^{28}$ Third, the Court introduced public forum doctrine as the operative mode of analysis for most

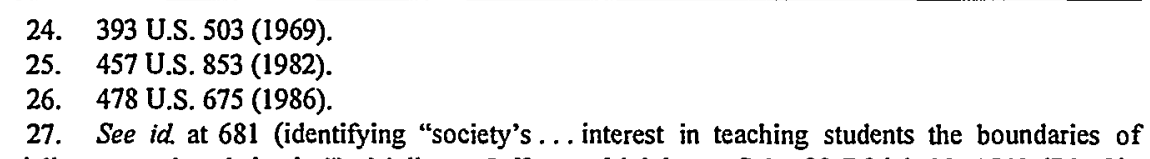
socially appropriate behavior"); Muller v. Jefferson Lighthouse Sch., 98 F.3d 1530, 1540 (7th Cir. 1996) (recognizing school concerns with "the inculcation of civility (including manners) and traditional moral, social, and political norms"); Virgil v. School Bd., 862 F.2d 1517, 1520 (11th Cir. 1989) (recognizing "the central role of public schools in transmitting values necessary to the development of an informed citizenry"); Broussard v. School Bd., 801 F. Supp. 1526, 1536 (E.D. Va. 1992) (recognizing school's legitimate "concern for values and decency in addition to school order"). This progression can be seen as a philosophical evolution from the pedagogical perspectives of John Dewey to Emile Durkheim. While Dewey argued that the schools were "an environment that molds citizenship and prepares people for democracy," Durkheim saw in schools "the need for social institutions to establish a core of consistent homogenizing values as a basis to enable children to develop their own autonomy." Michael Rebell, Tinker, Hazelwood and the Remedial Role of the Courts in Education Litigation, 69 ST. JoHN's L. REv. 539, 544-45 (1995).

28. See Hazelwood, 484 U.S. at 267. 
student speech cases, ostensibly abandoning its earlier mission-based inquiry. ${ }^{29}$ The eventual result is a doctrine that is mired in needless complexity and relies upon dubious facial commitments to governmental property interests or concerns that student speech might be attributed to the school.

\section{A. Tinker v. Des Moines}

In its initial foray into the realm of student speech, the Court focused its constitutional lens upon the mission of the school, assigning a mission to secondary school education and fashioning a constitutional test to match it. In Tinker $v$. Des Moines Independent Community School District, ${ }^{30}$ the Court struck down the suspensions of two high school students and one junior high student for wearing black armbands to protest the Vietnam War. ${ }^{31}$ The students, all siblings, planned the protest in advance and were not affiliated with any school-sponsored organization or activity. Setting the high-water mark for student liberties, the Court held that schools could prohibit student speech only if "engaging in the forbidden conduct would 'materially and substantially interfere with the requirements of appropriate discipline in the operation of the school." ${ }^{\prime 32}$ Because the lower court did not make the requisite finding, the symbolic speech of the armbands was entitled to constitutional protection.

The Court's ruling in Tinker was one more skirmish in a longstanding historical battle over the mission and goals of American education. ${ }^{33}$ While some saw education as a socialization mechanism designed to convey selected values, others saw it as an opportunity to exposc students to new ideas and options for the future. ${ }^{34}$ The Tinker decision took a clear position in the conflict, stating that "educating the young for citizenship is reason for scrupulous protection of Constitutional freedoms of the individual, if we are not to strangle the free mind at its source and teach youth to discount important principles of our government as mere platitudes. ${ }^{.35}$ The Court also mentioned "this Nation's

29. See id. at 270 .

30. 393 U.S. 503 (1969).

31. See id. at 514 .

32. Id. at 509 (quoting Burnside v. Byars, 363 F.2d 747, 749 (1966)) (emphasis added).

33. See generally amy Gutmann, Democratic Education (1987).

34. See Rosemary C. Salomone, Free Speech and School Governance in the Wake of Hazelwood, $26 \mathrm{GA}$. L. Rev. 253, 257 (1992) ("TThis ideology of schooling contains an inherent tension between individual freedom and collective interests."). For another perspective on the ideological history of American schooling, see Bruce C. Hafen \& Jonathan O. Hafen, The Hazelwood Progeny: Autonomy and Student Expression in the 1990's, 69 ST. JoHN's L. REv. 379 (1995).

35. 393 U.S. at 507 (quoting West Virginia State Bd. of Educ. v. Barnette, 319 U.S. 624, 637 (1943)). 
repudiation of the principle that a State might so conduct its schools as to "foster a homogenous people" 1336 and suggested that society can best discover truth "out of a multitude of tongues, [rather] than through any kind of authoritative selection. ${ }^{937}$ In addition, the Tinker Court placed a significant constitutional hurdle on the ability of school authorities by recognizing that "undifferentiated fear or apprehension of disturbance $^{938}$ was an insufficient institutional motive for speech regulation within the school community. ${ }^{39}$

The Court did not, however, entirely abandon the notion that school authorities have a legitimate interest in restricting the speech of their students. The "material or substantial disruption" test acknowledges that there is a point at which a school's disciplinary needs and larger objectives outweigh a student's interest in free speech. Because, by their very nature, material or substantial disruptions prevent meaningful communication from occurring, the Tinker test is not only a speech-friendly constitutional approach but also reflects a constitutional paradigm that sets limitations on speech that obstructs an organization's mission. If a school's mission is to foster dialogue and discourse as part of a search for truth, the Tinker Court argued, schools may restrict speech only when the speech impedes that mission. The Tinker test thus represents the Court's attempt to synthesize institutional realities with constitutional mandates.

\section{$B$. Board of Education v. Pico}

The first chinks in the Tinker armor began to appear in Board of Education v. Pico, ${ }^{40}$ decided in 1982 . A plurality of the Court held that a school district's decision to remove books from high school and junior high school libraries violated the First Amendment. ${ }^{41}$ The school district identified the books, which included Richard Wright's classic Black Boy and a compilation of short stories by African-American writers edited by Langston Hughes, ${ }^{42}$ as "anti-American, anti-Christian, anti-Sem[i]tic, and just plain filthy. ${ }^{343}$ The district went on to place the removal of the books in the context of an educational mission: "It is our duty, our moral obligation, to protect the children in our schools from this moral danger as surely as from physical and medical dangers." ${ }^{34}$

\footnotetext{
36. Id. at 511 (quoting Meyer v. Nebraska, 262 U.S. 390, 402 (1923)).

37. Id. at 512 (quoting Keyishian v. Board of Regents, 385 U.S. 589, 603 (1967)).

38. Id. at 508 .

39. Id. at 514 .

40. 457 U.S, 853 (1982).

41. See id. at 872 .

42. See id. at 856-57 n.3.

43. Id. at 857 .

44. Id.
} 
The plurality opinion, one of seven in the case, "is a studied lesson in Court confusion and ambivalence." ${ }^{\text {"45 }}$ While the decision turned primarily on whether the First Amendment extends to guarantee students access to information, ${ }^{46}$ Pico is doctrinally significant for our purposes in two respects. First, the Court suggested in dicta that courts should generally view the decisions of school districts with great deference. "[P] ublic education in our Nation is committed to the control of local and state authorities, and ... federal courts should not ordinarily "intervene in the daily operation of school systems." ${ }^{947}$ This deference represents a significant departure from the level of judicial scrutiny the Court suggested in Tinker, in which the Court presumed that speech restrictions were invalid unless the school could demonstrate that the speech would cause a material or substantial disruption.

Second, the Court began to hint at an alternative mission for American education that emphasized the inculcation of specific values rather than the importance of exposing students to a broad range of intellectual and cultural perspectives. "We are therefore in full agreement... that local school boards must be permitted 'to establish and apply their curriculum in such a way as to transmit community values,' and that 'there is a legitimate and substantial community interest in promoting respect for authority and traditional values be they social, moral, or political." $"$ While the Court did not entirely abandon the institutional objectives outlined in Tinker, by reminding school districts that "the First Amendment ... does not tolerate laws that cast a pall of orthodoxy over the classroom, ${ }^{249}$ the Court nevertheless sowed the doctrinal seeds for a shift away from Tinker.

\section{Bethel School District v. Fraser}

Decided just four years after Pico, Bethel School District v. Fraser ${ }^{50}$ presented the Court with an opportunity to reaffirm the relevance of Tinker's material or substantial disruption test. At a school assembly convened to elect officers for student government, a student gave a nominating speech for a fellow student that was laced with sexual innuendo. ${ }^{51}$ The school responded by suspending the student for three days

\footnotetext{
45. Salomone, supra note 34 , at 264 .

46. See Pico, 457 U.S. at 868.

47. Id. at 864 (quoting Epperson v. Arkansas, 393 U.S. 97, 104 (1968)).

48. Id.

49. Id. at 870 (quoting Keyishian v. Board of Regents, 385 U.S. 589,603 (1967)).

50. 478 U.S. 675 (1986).

51. The full text of the speech is as follows:

I know a man who is firm-he's firm in his pants, he's firm in his shirt, his character is firm-but most ... of all, his belief in you, the students of Bethel, is firm.
} 
and removing him from the list of candidates for graduation speaker. ${ }^{52}$ Relying on Tinker, the district and circuit courts overturned the suspension as a violation of the student's First Amendment rights. ${ }^{53}$

After acknowledging that the Tinker decision was still good law, ${ }^{54}$ the Court proceeded to tear it to shreds. Embracing Pico's redefinition of the mission of American public education, the Court stated, "[Public education] must inculcate the habits and ... values in themselves conducive to happiness and as indispensable to the practice of selfgovernment in the community and the nation. ${ }^{955}$ Backtracking on the question of school discretion, the Court stated that " $[t]$ he determination of what manner of speech in the classroom or in the school assembly is inappropriate properly rests with the school district." ${ }^{956}$ Ostensibly distinguishing Tinker as a case about political speech, ${ }^{57}$ the Court found that the school board had full authority to restrict "lewd and indecent" speech because such speech was "wholly inconsistent with the 'fundamental values' of public school education."

The most surprising element of the Fraser opinion is the lack of an operable constitutional test. Rather than following the test it articulated in Tinker, the Court conducted a Tinker-like inquiry into the mission of public school education and suggested that extending First Amendment rights to the school assembly would conflict with the organizational purpose of value inculcation. In so doing, the Court made no attempt to limit the holding to obscene speech or to provide any principles to guide lower courts as to when student speech impedes organizational objectives. Furthermore, the Court made no effort to confine or define the continued relevance of the Tinker test. ${ }^{59}$ The Court's ambiguity in this area had serious implications in terms of the degree of

Jeff Kuhlman is a man who takes his point and pounds it in. If necessary, he'll take an issue and nail it to the wall. He doesn't attack things in spurts-he drives hard, pushing and pushing until finally-he succeeds.

Jeff is a man who will go to the very end-even the climax, for each and every one of you.

So vote for Jeff for A.S.B. vice president-he'll never come between you and the best our high school can be.

Id. at 687 (Brennan, J., concurring).

52. See id at 678 .

53. See id. at $679-80$.

54. See id. at 680 .

55. Id. at 681 (quoting C. Beard \& M. Beard, New Basic History of the UNited States 228 (1968)).

56. Id. at 683.

57. Id. at 680 . Fraser's attempt to distinguish Tinker on the basis of political speech is ultimately unconvincing since the student speech in Fraser occurred at a schoolwide forum on self-government.

58. Id. at 685-86.

59. The Court could have applied the Tinker test and still reached the desired outcome. In his concurrence, Justice Brennan applied the Tinker test and found the speech "disruptive" and therefore found the suspension constitutional. See id. at 688-90 (Brennan, J., concurring). 
discretion granted to school authorities to regulate student speech. By failing to clarify the appropriate standard of review, the Court implicitly suggested a weakness in the affirmative proof of "disturbance" required under Tinker. ${ }^{60}$

In sum, between 1969 and 1986, the Court consistently inquired into the institutional mission of American schools to determine the boundaries of First Amendment liberties. As the Court's articulation of that mission began to shift from producing independent thinkers to articulating cultural values, the level of discretion the Court granted to school authorities to restrict student speech began to grow.

II

Public Forum Doctrine: The INTRODUCTION OF a Categorical Approach to Student Speech

The retreat from Tinker that the Court began in Pico and Fraser culminated in Hazelwood School District v. Kuhlmeier. ${ }^{61}$ In Hazelwood, the Court affirmed the constitutionality of institutional censorship of a school-sponsored newspaper. ${ }^{62}$ Staff members of a high school newspaper, the Spectrum, contested their school's decision to withhold publication of two stories. One story dealt with student experiences with pregnancy, the other with the impact of divorce on students in the school. ${ }^{63}$ Students wrote and edited the paper as part of a journalism course for which they received curricular credit, page proofs of each issue were submitted to the principal for his approval, and the local board supplied the majority of the operating funds for the paper. ${ }^{64}$

In order to understand the Court's decision, it is necessary to examine briefly public forum doctrine, an analytic tool that began to assume great importance in First Amendment analysis during the Burger and Rehnquist Courts. ${ }^{65}$ Public forum doctrine focuses on creating a series of categorical tests based upon the medium or locale where the speech takes place. In the process, forum analysis makes a distinction between viewpoint discrimination and content discrimination. ${ }^{66}$

60. See C. Thomas Dienes \& Annemargaret Connolly, When Students Speak: Judicial Review in the Academic Marketplace, 7 YALE L. \& PoL'Y REv. 343, 367 (1989) ("[A]t best, the Chief Justice urged a rationality standard of review; alternatively, he urged complete judicial abdication of first amendment review.").

61. 484 U.S. 260 (1988).

62. See id. at 262.

63. See id. at 263.

64. See id. at 262-63.

65. See Cornelius v. NAACP Legal Defense and Educ. Fund, Inc., 473 U.S. 788 (1985); Perry Educ. Ass'n v. Perry Local Educators' Ass'n, 460 U.S. 37 (1983). The doctrine can be traced to two sources: Harry Kalven, The Concept of the Public Forum: Cox v. Louisiana, 1965 Sup. CT. Rev. 1 (1965) and Hague v. CIO, 307 U.S. 496 (1939).

66. The Court's current approach to First Amendment doctrine evaluates regulations on speech 
Viewpoint discrimination is subject to strict constitutional scrutiny regardless of the forum classification, ${ }^{67}$ while content discrimination is dependent upon the nature of the forum. Forum analysis determines the state's ability to engage in content discrimination by dividing public spaces into three separate categories for the purpose of evaluating content-based restrictions: the public (or traditional) forum, the limited (or designated) public forum, and the non-public forum. ${ }^{68}$

Traditional public forums, described as places that "by long tradition or by government fiat have been devoted to assembly and debate," ${ }^{\prime 69}$ receive the highest level of constitutional protection for speech. In such forums, which include streets and parks, the government may not place absolute prohibitions on speech and may only institute content-based restrictions if they are "necessary to serve a compelling state interest and... [are] narrowly drawn to achieve that end."70 Speech in public forums is subject to reasonable time, place, and manner restrictions."

The second category, the limited public forum, is created when a government entity opens its property for use as a place of expressive activity for a limited amount of time or for a limited class of speakers. ${ }^{72}$ For example, in Widmar v. Vincent, ${ }^{73}$ the Court held that a university created a limited public forum for student groups that wished to meet on campus. ${ }^{74}$ In identifying limited public fornms, the Court does not look to the tradition of the forum, but to "the policy and practice of the government. ${ }^{375}$ If the government has established the confines of the forum, and the speech falls within the purpose of the forum, contentbased restrictions are subject to the same scrutiny as in traditional public forums. ${ }^{76}$

depending upon whether they seek to regulate the content or viewpoint of the speech. Content-based discrimination targets the subject matter of the speech while viewpoint discrimination targets the speaker's views on the subject. See, e.g., Rosenberger v. Rector and Visitors of the Univ. of Va., 515 U.S. 819, 830-31 (1995).

67. See id, ("Discrimination against speech because of its message is presumed to be unconstitutional.").

68. A comprehensive analysis or critique of public forum doctrine is beyond the scope of this Comment. For analyses and critiques of public forum doctrine, see generally Post, Between Governance and Management, supra note 19; Daniel A. Farber \& John E. Nowak, The Misleading Nature of Public Forum Analysis: Content and Context in First Amendment Adjudication, 70 VA. L . REv. 1219 (1984).

69. Perry, 460 U.S. at 45.

70. Id.

71. See id. and cases cited.

72. See Rosenberger, 515 U.S. at 829 .

73. 454 U.S. 263 (1981).

74. See id. at 277.

75. Comelius v. NAACP Legal Defense and Educ. Fund, Inc., 473 U.S. 788, 802 (1985) (emphasis added); see also Hazelwood Sch. Dist. v. Kuhlmeier, 484 U.S. 260, 270 (1988).

76. See Perry Educ. Ass'n v. Perry Local Educators' Ass'n, 460 U.S. 37, 45-46 (1983). 
All other forums are considered non-public. Within this category, the government may place restrictions "based on subject matter and speaker identity so long as the distinctions drawn are reasonable in light of the purpose served by the forum and are viewpoint neutral." 77 The government's rationale does not need to be the "most reasonable or the only reasonable limitation." ${ }^{78}$ Most important, unlike the other categories, "a finding of strict incompatibility between the nature of the speech or the identity of the speaker and the functioning of the nonpublic forum is not mandated." 79

\section{III}

\section{Hazelwood's REASONING AND ANALYSIS}

Hazelwood represents the Court's definitive attempt to reconcile two conflicting doctrinal objectives established by precedent. On one hand, Justice White's opinion began with the oft-quoted observation from Tinker that public school students "do not 'shed their constitutional rights to freedom of speech or expression at the schoolhouse gate" "\$80 and affirmed that schools may not sanction students "merely for expressing their personal views on the school premises" ${ }^{\text {"II }}$ unless the school satisfies the demands of the Tinker test. At the same time, the Court went on to validate the primary tenets of Fraser: Schools need not tolerate speech that threatens the school's mission, ${ }^{82}$ and school boards have peremptory authority to determine the scope of permissible speech "in the classroom or in school assembly."

Hazelwood's attempt at reconciling precedent involved the use of two fundamentally flawed and highly interrelated concepts: public forum doctrine and a constitutional dichotomy between "school-sponsored" and "school-tolerated" 84 speech. A critique of both concepts reveals a school speech doctrine that is almost impossible to apply with any sort of constitutional consistency and without threatening the integrity of core First Amendment values.

77. Cornelius, 473 U.S. at 806 .

78. Id. at 808 .

79. Id.

80. 484 U.S. at 266 (quoting Tinker v. Des Moines Indep. Community Sch. Dist., 393 U.S. 503, $506(1969))$.

81. Id.

82. See id. at 266 ; see also id. at 272 ("Otherwise, the schools would be unduly constrained from fulfilling their role as 'a principal instrument in awakening the child to cultural values, in preparing him for later professional training, and helping him to adjust normally to his environment.") (quoting Brown v. Board of Educ., 347 U.S. 483, 493 (1954)).

83. Id. at 267 (quoting Bethel Sch. Dist. No. 403 v. Fraser, 478 U.S. 675,683 (1986)).

84. See Rosemary C. Salomone, Public Forum Doctrine and the Perils of Categorical Thinking: Lessons from Lamb's ChapeI, 24 N.M. L. REv. I, 19 (1994). 


\section{A. Hazelwood's Use of Public Forum Doctrine}

For the first time in a case involving student speech, the Court applied public forum analysis to determine whether speech is constitutionally protected. Examining the Spectrum, the Court identified the paper as a non-public forum because there was no evidence of school policy or practice "to open the pages of Spectrum to 'indiscriminate use' ... by its student reporters and editors, or by the student body generally." part of its inquiry into the paper's role as a vehicle for self-expression, the Court relied on the paper's close relationship to the school curriculum and the trial court's finding that the journalism teacher and the principal had final authority over the content of the paper. ${ }^{86}$

By applying public forum doctrine in Hazelwood, the Court utilized an analysis that was developed to answer one question-whether the government must grant equal access to government property and media for external speakers-to answer a very different question: whether speakers from within the school environment are entitled to protection from content- and viewpoint-based discrimination. ${ }^{87}$ The two circumstances involve fundamentally different constitutional considerations.

When applying public forum doctrine to external speakers, the Court has consistently focused on the government's ownership of the property to justify content-based regulation. ${ }^{88}$ "[T] $[$ he state, no less than a private owner of property, has the power to preserve the property under its control for the use to which it is lawfully dedicated." government dedicates the property to free expression, either by policy or tradition, the state is restricted from engaging in content-based exclusions. Otherwise, public forum doctrine treats the government like any other private business, with wide latitude to restrict speech based upon content. ${ }^{90}$

With internal speech, the rationale used to justify exclusion of outside speakers under public forum doctrine becomes highly suspect. If government's power to regulate speech under public forum doctrine is directly tied to government ownership of property, this would suggest that the government has nearly unlimited ability to impose content regulations on individuals that spend the bulk of their time, as

85. Hazelwood, 484 U.S. at 270.

86. See id. at 268-69.

87. See supra note 66 for an explanation of the distinction between content- and viewpointbased discrimination. See generally Post, Between Governance and Management, supra note 19.

88. See id. at 1766.

89. Perry Educ. Ass'n v. Perry Local Educators' Ass'n, 460 U.S. 37, 46 (1983) (quoting Greer v. Spock, 424 U.S. 828,836 (1976)). For a critique of the Court's focus on property rights, see Cornelius v. NAACP Legal Defense and Educ. Fund, Inc., 473 U.S. 788, 821-22 (1985) (Blackmun, J., dissenting) ("[T]he mere fact that the Government acts as property owner should not exempt it from the First Amendment.").

90. See supra note 77 and accompanying text. 
government employees or as students, on government property that is not a designated public forum. Suppose, for example, that the Department of Health and Human Services, concerned that its employees are not spending enough time discussing the major social problems of the day, barred all of its employees, when on HHS property and engaging in HHS business, from any and all speech related to the topics of sports and entertainment. Courts would likely find this type of contentbased regulation of internal speech unconstitutional.." ${ }^{91}$ But why? If we accept that the State may engage in content-based exclusion of internal speakers merely because it owns the property, such a regulationwhether it involves HHS, the Tinker armbands, or queer student groups-should withstand constitutional scrutiny.

The application of public forum doctrine to internal speech leads to skewed constitutional outcomes. By applying a doctrine whose rationale is based on the government's role as a property owner to cases where the government functions as an employer or as a provider of social communities, courts are destined to overlook constitutional values of free expression and open political discourse. The potential for undesirable outcomes forced the Hazelwood Court to explore creative constitutional alternatives, adding confusion to an already muddled area of law.

\section{B. Hazelwood and School-Sponsored Speech}

Taken by itself, the use of public forum doctrine in Hazelwood likely would have overruled Tinker..$^{92}$ If internal speech, without regard to the affiliation of the speaker, was regulated within the broad confines of the non-public forum, the school would have the same right to regulate student armbands as it would have to deny access to an Avon lady who wants to make an on-site presentation to faculty and staff.

To avoid this outcome, the Hazelwood Court added a schoolspecific corollary to its application of public forum doctrine. Addressing the question it avoided in Fraser, the Court clarified the scope of the Tinker test by making a crucial distinction between school-sponsored and school-tolerated speech. The Court restricted application of the Tinker test to school-tolerated speech, defined as "a student's personal expression that happens to occur on the school premises. ${ }^{993}$ Hazelwood, alternatively, dealt with school-sponsored speech, "educators' authority

91. This is, obviously, an overly simplistic example. In an educational context, a court would likely decide this type of case under Pickering v. Board of Education, 391 U.S. 563 (1968), examining whether the school employee's relationship with the local board was close enough to require "personal loyalty and confidence" in order to function properly. Id. at 570.

92. See Cornelius, 473 U.S. at 823 n.3 (Blackmun, J., dissenting) (stating that the Court's application of public forum doctrine would overrule Tinker).

93. Hazelwood, 484 U.S. at 271. 
over school-sponsored publications, theatrical productions, and other expressive activities that students, parents, and members of the public might reasonably perceive to bear the imprimatur of the school.994

The Court defined the scope of school-sponsored speech to include any activity, inside or outside a traditional classroom setting, that is "supervised by faculty members and designed to impart particular knowledge or skills to student participants and audiences."995 Hence, the Tinker test is not applicable to determine "when a school may refuse to lend its name and resources to the dissemination of student expression." ${ }^{.96}$ High schools can engage in speech regulation connected to "school-sponsored expressive activities so long as their actions are reasonably related to legitimate pedagogical concerns." degree of constitutional scrutiny dependent upon school sponsorship, the Hazelwood Court saved Tinker from the fatal effects of public forum doctrine. The end result, however, only replaced one doctrinal tangle with another.

The problematic questions raised by the use of school sponsorship as a governing constitutional principle are readily apparent in the case of high school student organizations. Should the Court have decided Tinker differently if the Tinker children's protest had been part of an activity sponsored by the "Oppose the Vietnam War" club at school? Would constitutional protection for such a club hinge on whether a faculty member supervised a protest organized by the club? Or whether the school established the club for the ostensible purpose of imparting particular leadership and organizing skills? Are voluntary extracurricular student organizations fundamentally different from the schoolwide assembly in Fraser or the newspaper in Hazelwood, which was distributed throughout the school? Furthermore, how should a court analyze an extracurricular queer student group's decision to wear pink triangles in class?

In sum, the Hazelwood Court introduced two significant doctrinal elements into the dialogue over constitutional protections for student speech. First, Hazelwood applied public forum doctrine to intraorganizational speech, even though the doctrine was developed to establish constitutional boundaries for access by outsiders to government property. Second, by utilizing the sponsorship/toleration distinction to determine the degree of First Amendment protection, the Court ostensibly abandoned the mission-based analysis it had advanced in previous cases in favor of a hybrid categorical analysis.
94. Id.
95. Id.
96. Id. at 272-73.
97. Id. at 273. 


\section{IV}

\section{APPlying the Doctrine to Student Clubs}

While Hazelwood's emphasis on public forum doctrine and school sponsorship severely limited Tinker's reach, existing doctrine offers student clubs some limited hope for First Amendment protection. In this Part, I apply both public forum doctrine and Hazelwood to a ban on student clubs in order to elaborate on some of the doctrinal problems addressed earlier as well as to suggest ways that courts addressing regulations on student clubs might distinguish Hazelwood.

\section{A. Public Forum Doctrine and Student Clubs}

Despite their divergent outcomes, Tinker and Fraser adopted similar approaches to First Amendment questions. Both cases inquired into the mission of an educational institution as a mechanism for determining the relative strength of the school's interest in restricting speech. The Court then based its decision upon the degree to which the speech threatened the mission. Public forum doctrine ostensibly supplants this approach because it centers its constitutional inquiry not on governmental interests and objectives, but on the medium or locale where the speech takes place. ${ }^{98}$

To understand public forum doctrine's potentially lethal consequences for speech in an educational environment, consider the case of queer student clubs. The doctrine offers the clubs two potential safe harbors that have succeeded in post-secondary environments, but both are fraught with problems. At the same time, both solutions pinpoint problems inherent in public forum doctrine: the definition of the "limited public forum" and the scope of the ban on viewpoint discrimination.

First, the clubs may argue that student clubs are a limited public forum, and the school therefore may not engage in content- or viewpoint-based discrimination. Indeed, this argument has worked with great success in a college context, ${ }^{99}$ providing First Amendment protection to queer student groups at universities. ${ }^{100}$ More importantly, Hazelwood itself contains language suggesting that the use of school facilities by student groups might constitute a limited public forum. ${ }^{101}$

98. See Post, Between Governance and Management, supra note 19, at 1765-66.

99. See, e.g., Widmar v. Vincent, 454 U.S. 263 (1981) (overturning university policy of excluding religious groups from university facilities).

100. See, e.g., Gay Lesbian Bisexual Alliance v. Pryor, 110 F.3d 1543 (11th Cir. 1997) (holding statute prohibiting recognition of qucer student group unconstitutional).

101. See Hazelwood, 484 U.S. at 267 ("[S]chool facilities may be deemed to be public forums only if school authorities have 'by policy or by practice' opened those facilities 'for indicriminate usc by the general public,' or by some segment of the public, such as student organizations." (quoting Perry Educ. Ass'n v. Perry Local Educators' Ass'n, 460 U.S. 37, 47 (1983) (emphasis added))); see 
Unfortunately, the Court's definition of the "limited public forum" category has rendered it all but meaningless..$^{102}$ If, as the Court asserts, a high school, or any other government institution, can create and define the scope of the limited public forum through its "policy and practice, ${ }^{\prime 103}$ a school district or the state legislature may simply include content-based exclusions in the definition of the forum, as Utah did with clubs that "involve human sexuality." Under public forum doctrine, courts could easily consider the Utah statute as an indication of the state's "policy and practice"toward excluding student organizations that "involve human sexuality," effectively removing such clubs from the class of speakers entitled to the limited public forum's heightened constitutional scrutiny. As a result, it is increasingly difficult to determine whether the "limited public forum" category has any real constitutional significance, or if it has become part and parcel of the "non-publicforum."

Second, even if a court treated student clubs as non-public forums, a queer club may still argue that a ban on clubs that address human sexuality constitutes impermissible viewpoint discrimination. The Court has already accepted a parallel argument in the context of college clubs, striking down the University of Virginia's denial of funding to a Christian student organization in Rosenberger $v$. Rector and Visitors of the University of Virginia. ${ }^{104}$ The Court's reliance, however, on viewpoint discrimination, regardless of the educational setting or the outcome for student groups, is misplaced because it is impossible to apply the ban on viewpoint discrimination in a consistent and principled manner.

The fact remains that the contemporary American high school is a rich gold mine of viewpoint discrimination. ${ }^{105}$ Consider schoolwide assemblies on a particular topic or classroom assignments that ask

also Perry, 460 U.S. at $46 \mathrm{n} .7$ (stating that institutions may create public forums for use by student groups).

102. See Comelius v. NAACP Legal Defense and Educ. Fund, Inc., 473 U.S. 788, 825 (1985) (Blackmun, J., dissenting):

The Court makes it virtually impossible to prove that a forum restricted to a particular class of speakers is a limited public forum. If the Government does not create a limited public forum unless it intends to provide an 'open forum' for cxpressive activity, and if the exclusion of some speakers is evidence that the Government did not intend to create such a forum, no speaker challenging denial of access will ever be able to prove that the forum is a limited public forum.

Id. (citation omitted).

103. Cornelius, 473 U.S. at 802; see also Hazelwood, 484 U.S. at 270.

104. 515 U.S. 819 (1995). While a ban on clubs that address human sexuality would seem to constitute content discrimination, the Rosenberger Court held that a policy denying funding to a student group that manifests a "belief in or about a deity or ultimate reality" constituted viewpoint discrimination. Id. at 836. In the process, the Court recognized that the distinction between content and viewpoint discrimination is "not a precise one." Id. at 831.

I05. See Robert C. Post, Subsidized Speech, I06 Y ALE L.J. 15I, 165-67 (1996). 
students to take a particular position, like "Why Capitalism Promotes Economic Efficiency." The assignment, though likely to survive constitutional scrutiny, ${ }^{106}$ clearly violates the constitutional ban on viewpoint discrimination because it effectively silences those with other viewpoints on the comparative merits of capitalism. If the Court were truly serious about imposing an absolute ban on viewpoint discrimination, educational pedagogy as we know it would cease to exist. While attempts to justify protection for controversial high school student organizations based upon the categorical ban on viewpoint discrimination are doctrinally possible, such claims are particularly tenuous given the unique nature of the school environment.

\section{B. Hazelwood and Student Clubs}

The Supreme Court has never explicitly addressed the constitutional free speech rights of extracurricular high school clubs. Moreover, the Equal Access Act has enabled lower courts to dispose of student club cases involving speech regulations on statutory grounds, ${ }^{107}$ allowing those courts to avoid ruling on any constitutional claim. Nevertheless, there are some potential ways to distinguish Hazelwood's definition of sponsorship and place student groups within Tinker's protective umbrella.

Most noticeably, the newspaper in Hazelwood was part of a journalism class for which the students received curricular credit. ${ }^{108}$ The faculty adviser and principal were actively involved in the editorial process, and the paper was widely distributed throughout the school..$^{109}$ In contrast, most student clubs do not implicate these indicia of sponsorship to the same degree. Curricular credit is rarely granted for student club activity, and institutional review of the speech of student clubs is, in most cases, comparatively minimal.

Because Hazelwood offers such a broad definition of sponsorship, however, courts cannot easily dismiss it. Hazelwood extends its reach beyond standard curricular speech to "school-sponsored publications, theatrical productions, and expressive activities that students, parents, and members of the public might reasonably perceive to bear the imprimatur of the school."110 If a school district can show that a club's activities "are supervised by faculty members and designed to impart

106. See, e.g., Settle v. Dickson County Sch. Bd., 53 F.3d 152 (6th Cir. 1995) (holding that assigning a student a grade of zero for a proposed paper on the life of Jesus Christ did not violate the student's free speech rights).

107. See supra note 23.

108. See Hazelwood, 484 U.S. at 262.

109. See id. at 261-62.

110. Id. at 271 . 
particular knowledge or skills to student participants,"111 then a reviewing court would have to utilize Hazelwood's limited conception of constitutional scrutiny. Furthermore, some lower courts have shown a willingness to extend Hazelwood beyond the confines of curricular speech. ${ }^{12}$

\section{The Interplay between Public Forum Doctrine and Sponsorship}

The overlap between the sponsorship/toleration distinction and public forum doctrine has been the subject of significant disagreement among lower courts. In cases where the school demonstrates sponsorship, courts have either conducted a forum analysis ${ }^{113}$ or simply applied the Hazelwood test and dispensed with forum analysis entirely. ${ }^{114}$ In either approach, the outcome was fairly predictable, as the First Amendment places few limits on the ability of schools to regulate school-sponsored speech.

In cases involving the personal speech of students ("Tinker" speech), however, courts have split on whether or not Tinker preempts a forum-based inquiry. ${ }^{115}$ Because Tinker and public forum doctrine adopt dramatically different perspectives on the appropriate degree of judicial deference, the applicable test has a significant impact on the First Amendment rights of students who engage in non-school-sponsored speech on school grounds. Several courts have applied forum analysis to non-school-sponsored speech, ${ }^{116}$ examining whether or not restrictions on non-school sponsored speech are permissible in specific areas of the

111. Id.

112. See, e.g., Crosby v. Holsinger, 852 F.2d 801 (4th Cir. 1988) (holding that school did not violate First Amendment by banning the school's "Johnny Reb" symbol); C.H. v. Oliva, 990 F. Supp. 341, 352-54 (D.N.J. 1997) (applying Hazelwood to find that school did not violate First Amendment by moving student's poster of Jesus to a less prominent location).

113. See, e.g., Planned Parenthood of S. Nev., Inc. v. Clark County Sch. Dist., 941 F.2d 817 (9th Cir. 1991) (en banc) (holding that a school-sponsored yearbook was permitted to reject advertisements by Planned Parenthood because the yearbook was a non-public forum).

114. See, e.g., Settle v. Dickson County Sch. Bd., 53 F.3d 152 (6th Cir. 1995); Poling v. Murphy, 872 F.2d 757 (6th Cir. 1989) (holding that disqualification of candidate for student council president for insulting assistant principal in campaign speech did not violate the First Amendment); Crosby, 852 F.2d 801. There is no substantive difference between the two tests, since they both demand a reasonable relationship between the regulation on speech and the purpose served by the forum. In the case of schools, the purpose is to address "legitimate pedagogical conccrns." Searcey v. Harris, 888 F.2d 1314, 1319 (11th Cir. 1989) (quoting Hazelwood, 484 U.S. at 273) (stating that there is no difference between the two tests). However, the Court has given some recent indications that this distinction may be meaningful with respect to the ability of school districts to engage in viewpoint discrimination. See infra note 144.

115. See Salomone, supra note 34, at 274-92.

116. See, e.g., Muller v. Jefferson Lighthouse Sch., 98 F.3d 1530 (7th Cir. 1996) (holding that because an elementary school is a non-public forum, the school did not violate a fourth-grader's First Amendment rights by forbidding him from distributing invitations to a church function on school grounds). 
school, like school hallways. ${ }^{117}$ Others have ignored public forum doctrine altogether and applied the Tinker test, implicitly reasoning that public forum doctrine is restricted to questions of access, not to those of students' personal expression in places where they are already entitled to be. ${ }^{118}$ While the resolution of this conflict is beyond the scope of this Comment, the problem is demonstrative of the confusion that has accompanied the application of a doctrine that deals with external access to public space to the workings of an internally driven community. ${ }^{119}$

\section{V}

\section{A Critique of School Sponsorship}

Because Hazelwood's applicability to extracurricular student clubs is somewhat ambiguous, it is necessary for reviewing courts to examine the underlying motivations behind the opinion. In this Part, I consider the tremendous emphasis the Hazelwood Court placed on the issue of sponsorship and question why the issue of sponsorship should have any constitutional significance at all. I offer two likely rationales and explain why both fail to justify the use of sponsorship as a determinative factor in school speech cases.

Under the first rationale, which I will call the "proprietary"justification, ${ }^{120}$ sponsorship is significant because the school has a right to restrict speech based on its interest in the property upon which the speech takes place or based on the school's ability to allocate its own resources. As suggested earlier, this concept functions as the guiding assumption behind public forum doctrine. ${ }^{121}$ Under the second, which I will call the "attribution"rationale, schools attempt to justify content-based exclusions of "school-sponsored" speech because the school, like any individual or organization, may decide with what speech it chooses to affiliate itself.

117. See Hemry v. School Bd. of Colo. Springs Sch. Dist. No. 11, 760 F. Supp. 856 (D. Colo. I991) (upholding school's restriction on student distribution of religious newspaper in school hallways).

118. See, e.g., Chandler v. McMinnaville Sch. Dist., 978 F.2d 524 (9th Cir. I992) (holding that suspension of students for their refusal to remove buttons containing the word "scab" to support teachers' strike violated First Amendment); Burch v. Barker, 861 F.2d 1149 (9th Cir. 1988) (holding unconstitutional a school policy requiring pre-distribution school approval of all student-written materials as applied to unauthorized student-written newspaper); Chalifoux v. New Caney Indep. Sch. Dist., 976 F. Supp. 659 (N.D. Tex. I997) (upholding students' First Amendment right to wear rosaries as necklaces). But see Broussard v. School Bd., 80I F. Supp. I526, I537 (E.D. Va. 1992) (applying Tinker test to find no First Amendment violation in school's decision to suspend student for wearing T-shirt saying “Drugs Suck!").

119. See supra note 87 and accompanying text.

120. See generally Post, Between Governance and Management, supra note 19.

121. See supra Part 111.A. 


\section{A. Proprietary Justification}

As applied to the question of queer student groups, the proprietary rationale goes something like this: Because the school district owns the property on which the club wishes to meet, and because the school supplies resources to the club, the district, as a property owner or resource provider, is entitled to preserve the property for its intended uses. Thus, queer student groups have no constitutional rights to meet on school property during school hours. ${ }^{122}$ The Court has invoked this general type of rationale on many occasions, primarily in the context of public forum doctrine, to explain the government's ability to deny access to property. ${ }^{123}$

For the same reasons that the proprietary rationale fails in the public forum context, it cannot explain the Hazelwood Court's preoccupation with sponsorship. If the sole justification for sponsorship were to protect the government's property rights, the Court would have subjected the speech of the Tinker children to regulation merely because the school supplied the classroom where the speech took place. Consequently, any student club or organization meeting on school property or using school resources to facilitate speech would be subject to nearly limitless regulation. The proprietary justification, if taken at face value, recognizes no distinction between personal expression in a school lunchroom and speech that somehow implicates the school. If taken to its logical conclusion, this justification would allow a school, in the name of promoting its desired values, to expend its resources to allow only students with family incomes above $\$ 50,000$ to participate in student clubs or to allow only the school Democratic club to meet. ${ }^{124}$ These types of hypothetical regulations, which present clear constitutional problems, suggest that a school should not have a nearly unlimited

122. The question of whether queer student groups can meet after school on school property is a fundamentally different question. See Lamb's Chapel v. Center Moriches Union Free Sch. Dist., 508 U.S. 384 (1993) (holding unconstitutional school's denial of church's request to use school facilities for film series); Good News/Good Sports Club v. School Dist., 28 F.3d 1501 (8th Cir. 1994) (overturning school policy forbidding access to student religious club after school as impermissible viewpoint discrimination); Gregoire v. Centennial Sch. Dist., 907 F.2d 1366 (3d Cir. 1990) (upholding preliminary injunction forcing school to allow student religious organization to rent out the school auditorium after school).

123. See, e.g., Lamb's Chapel, 508 U.S. at 390 ("There is no question that the District, like the private owner of property, may legally preserve the property under its control for the use to which it is dedicated." (citing Cornelius v. NAACP Legal Defense and Educ. Fund, Inc., 473 U.S. 788, 800 (1985))).

124. See Board of Educ. v. Pico, 457 U.S. 853, 870-71 (1982) ("If a Democratic school board, motivated by party affiliation, ordered the removal of all books written by or in favor of Republicans, few would doubt that the order violated the constitutional rights of the students ...."). While some might view the latter regulation as impermissible viewpoint discrimination, subsequent interpretations of Hazelwood suggest that school sponsorship allows schools to engage in viewpoint discrimination. See infra note 144. 
license to engage in speech regulation solely based on a proprietary justification.

\section{B. Attribution Rationale}

Under the attribution rationale, queer student groups have limited First Amendment rights because external observers and members of the school community may perceive the students' speech as the speech of the school. Because the Constitution grants broad latitude for the government to select which messages it wishes to convey when the governmental entity is the speaker, ${ }^{125}$ the school could casily subject the club to regulation. However, the rationale fails to account for the full scope of a school's authority to regulate student speech. In addition, the justification does not account for the organizational relationship between clubs and schools and does not adequately explain the doctrinal distinction the Court has drawn between student speech rights in high schools and universities.

\section{Underinclusion: The Risk of Attribution Fails to Explain the Full Scope of the School's Regulatory Power}

Taken by itself, the attribution rationale cannot justify the level of discretion granted to school authorities because the rationale is underinclusive. Consider the following hypothetical interaction in a high school biology class:

Teacher: What does Darwin's theory of evolution say?

Student: I know I am just expressing my own opinion here, but I would suggest that everything Darwin said about evolution is wrong. God created the universe and human beings, and evolution is a bunch of lies.

Teacher: That's not what I'm looking for, and I would appreciate it if you didn't bring that issue up again [effectively silencing the student].

Under current doctrine, schools retain the power to regulate such in-class student statements made during the course of an academic exchange, ${ }^{126}$ much like the newspaper in Hazelwood, even though the student has added a disclaimer, and there is little danger that anyone would attribute the student's statement to the school. For in-class dialogues, the risk of attribution is almost non-existent, but the power of school authorities remains paramount. Clearly, the rationale is underinclusive

125. See Rust v. Sullivan, 500 U.S. 173 (1991).

126. See Settle v. Dickson County Sch. Bd., 53 F.3d 152 (6th Cir. 1995); C.H. v. Oliva, 990 F. Supp. 341, 352-54 (D.N.J. 1997) (finding that school district did not violate First Amendment by preventing student from reading children's Bible story to his classmates). 
because it fails to explain the full scope of the school's authority to regulate school-sponsored speech, including the speech of student clubs.

\section{The Attribution Rationale Fails to Account for the Organizational Relationship Between Student Clubs and Their Schools}

When applied to student clubs, the attribution rationale ignores the organizational relationship between student clubs and their parent institutions. By and large, participation in a particular club is a voluntary act initiated by an individual student. ${ }^{127}$ Students, not faculty members or school administrators, define the organization's agenda, allocate funds, organize activities, elect officers, and schedule meetings. The existence of a faculty sponsor, whose role is usually advisory and is designed to minimize tort liability from injuries to person or property, is insufficient to implicate the school. If faculty presence alone were sufficient to justify speech regulation, the presence of faculty members during lunch recess or during the Tinker students' protest would justify speech restrictions. Furthermore, schools routinely permit student groups with divergent or conflicting objectives to meet without adopting either group's position.

Unlike the student speech at issue in Hazelwood or Fraser, student organizations do not generally involve speech aimed at, or distributed to, the entire student body. ${ }^{128}$ Consequently, the risks of implying school sponsorship of the speech are dramatically minimized, as the communication is only among students who are voluntary participants. ${ }^{129}$ Additionally, in contrast to the newspaper in Hazelwood, queer student clubs have no connection to the school's curriculum. Hazelwood involved a journalism class for which participants received curricular credit, perhaps the most tangible representation of the school's imprimatur. The average student club, like the stamp club or the Future Farmers of America, has a comparatively distant relationship to the school's curriculum, which lessens the risk of attribution and provides courts with a means for distinguishing Hazelwood.

127. This assumes that participation in student groups is voluntary and that the governance of the clubs and content of the meetings is in the hands of students. These two criteria are crucial. If either one is not satisfied, the student clubs become more like an academic classroom where student attendance is mandatory and the curriculum is controlled by the institution.

128. See D. Jarrett Arp, Beyond Mergens: Balancing A Student's Free Speech Right Against the Establishment Clause in Public High School Equal Access Cases, 32 WM. \& MARY L. REv. 127, 134 (1990). While it is true that many student organizations post fliers or advertisements targeting the entire school community, the bulk of speech activity within clubs generally occurs in more private and contained settings.

129. Cf. Silano v. Sag Harbor Union Free Sch. Dist. Bd. of Educ., 42 F.3d 719, 723 (2d Cir. 1994) (distinguishing between curricular materials and library resources based upon the voluntariness of student exposure). 
Recognizing the potential for a narrow interpretation of Hazelwood, some lower courts have scrutinized the organizational relationship between the school and the club in order to avoid the confines of Hazelwood's limited definition of student speech rights. For example, in Clark v. Dallas Independent School District, ${ }^{130}$ a district court upheld the right of a student-initiated religious club to meet before school, overturning the school district's categorical ban on religious student organizations. The court applied the Tinker test, distinguishing Hazelwood based upon its finding that " $[\mathrm{t}]$ he conduct at issue was voluntary, student-initiated, and free from the imprimatur of school involvement." ${ }^{\text {131 }}$

\section{The Attribution Rationale Fails to Account for Doctrinal Distinctions between High Schools and Colleges}

Trying to understand the Court's preoccupation with sponsorship becomes even more difficult when one contrasts Hazelwood with the Court's major rulings upholding the First Amendment rights of college student clubs. In a pair of decisions, Widmar $v$. Vincent ${ }^{132}$ and Rosenberger v. Rector and Visitors of the University of Virginia, ${ }^{133}$ the Court supported the rights of religious student organizations to meet and receive funding from universities, despite sponsorship conditions in a college context that were substantially identical to those of the average high school. Sponsorship, as a governing principle for student speech, is therefore insufficient to explain the differences between the First Amendment rights of high school and college students.

\section{a. Widmar and Hazelwood}

In Widmar v. Vincent, the Court overturned a state university's policy of excluding student religious groups from using university facilities. ${ }^{134}$ Reasoning that the university had created a limited public forum for student groups without any explicit intent to do so, ${ }^{135}$ the Court held that the university's regulation could not withstand the heightened constitutional scrutiny that attaches to such forums. ${ }^{136}$

If university ownership of property or attribution risks were not sufficient to allow for regulation of internal specch in Widmar, it is difficult to accept either rationale as the principle governing sponsorship in Hazelwood. Furthermore, Widmar holds that educational institutions

130. 806 F. Supp. 116 (N.D. Tex. 1992).

131. Id. at 120 .

132. 454 U.S. 263 (1981).

133. 515 U.S. 819 (1995).

134. See Widmar, 454 U.S. at 277.

135. See id. at 267-68.

136. See id. at 269-77. 
can unintentionally create a limited public forum for student groups despite a "policy and practice" of excluding religious organizations, while Hazelwood suggests that the school's policies and practices are definitive in judicial attempts to determine whether a limited public forum exists. ${ }^{137}$ The result of these cases leaves a court reviewing school speech restrictions without a principled means for dealing with the constitutional rules applicable to high school student organizations under the public forum doctrine or sponsorship analysis. Either Widmar has no application to high schools despite similar sponsorship conditions, or public high schools can unintentionally create a limited public forum for student organizations in spite of existing policies and practices.

Recognizing the potential for conflict in its treatment of high schools and colleges, the Widmar Court limited the scope of its holding in dicta by stating that "First Amendment rights must be analyzed 'in light of the special characteristics of the school environment" $" 138$ and noting that college students are "less impressionable than younger students." 139 Despite the Court's limited attempts at creating a distinction, however, the question of Widmar's applicability to public schools has been the subject of extensive debate among the lower courts. ${ }^{140}$ Passage of the Equal Access Act, ${ }^{141}$ designed to apply the Widmar decision statutorily to secondary schools, has not clarified Widmar's applicability to public high schools in a constitutional context.

One can reconcile Widmar and Hazelwood, however, once considerations of forum classification and sponsorship are abandoned. The central difference between the two cases is the Court's explanation of the respective missions of universities and high schools. If the Court accepts that the proper inquiry is not whether the speech is "schoolsponsored" or the nature of the forum, but whether the speech represents a threat to the institutional mission, Widmar and Hazelwood fit

137. See Hazelwood, 484 U.S. at 267.

138. Widmar, 454 U.S. at 268 n.5. (quoting Tinker v. Des Moines Indep. Sch. Dist., 393 U.S. 503, $506(1969))$.

139. Id. at $274 \mathrm{n} .14$; see also Muller v. Jefferson Lighthouse Sch., 98 F.3d 1530, 1538 (7th Cir. 1996) ("Age is a critical factor in student speech cases.").

140. Lower courts have used the Widmar decision to find limited public forums in high schools in a number of different contexts. See Bell v. Little Axe Indep. Sch. Dist., 766 F.2d 1391, 1401 (10th Cir. 1985) (using Widmar to find a limited public forum in an elementary and secondary school); Bender v. Williamsport Area Sch. Dist., 741 F.2d 538, 547 (3d Cir. 1984), rev'd on other grounds, 475 U.S. 534 (1986) (holding that high school created limited public forum for extracurricular student groups and stating, "The fact that Widmar involved a university, while we here are concerned with a high school, does not mean that we are free to ignore the nature of the free speech rights enjoyed by students."). But see Ceniceros v. San Diego Unified Sch. Dist., 66 F.3d 1535, 1546 (9th Cir. 1995) (holding Widmar inapplicable in an Establishment Clause context); Lubbock Civil Liberties Union v. Lubbock Indep. Sch. Dist., 669 F.2d 1038, 1045 (5th Cir. 1982) (holding Widmar inapplicable to a public school district).

141. See 20 U.S.C. $\$ \S 4071-4074$ (1994). 
together quite nicely. In Widmar, the Court simply found the restrictions incompatible with the mission of higher education to promote intellectual dialogue and debate. In Hazelwood, the Court dealt with a different mission at the secondary school level and found the restriction consistent with larger objectives of value inculcation.

\section{b. Rosenberger: Student Clubs and Governmental Speech}

In Rosenberger, the Court struck down the University of Virginia's policy of denying funding to student groups that promoted or manifested beliefs "in or about a deity or ultimate reality." "142 The Rosenberger majority held that governmental expenditure of resources to student organizations to encourage a diversity of viewpoints must conform to higher constitutional safeguards for free speech, including a ban on viewpoint discrimination. ${ }^{143}$ Curiously, both the majority and dissent relied on Hazelwood for the proposition that the government may engage in both content and viewpoint discrimination with respect to its own speech. ${ }^{144}$

Two relevant insights emerge from Rosenberger's use of Hazelwood. First, the fact that the Rosenberger Court regarded the Hazelwood newspaper's speech as the speech of the school shows that the Court views attribution as the governing rationale behind school sponsorship. ${ }^{145}$ Second, by suggesting that schools may engage in viewpoint-based as well as content-based discrimination, the Court indicates that public forum doctrine, which subjects viewpoint discrimination to

142. Rosenberger v. Rector and Visitors of Univ. of Virginia, 515 U.S. 819, 825 (1995).

143. See id. at 836-37.

144. See id. at 834 (citing Hazelwood for the proposition that "[a] holding that the Univcrsity may not discriminate based on the viewpoint of private persons whose speech it facilitates does not restrict the University's own speech, which is controlled by different principles"); id. at 892.93 n.11 (Souter, J., dissenting) (using Hazelwood to voice agreement with majority's distinction between "a State's use of public funds to advance its own speech and the State's funding of private spcech, suggesting that authority to make content-related choices is at its most powerful when the State undertakes the former"). Rosenberger's use of Hazelwood reflects the Court's misunderstanding and current confusion over public forum doctrine and its application to internal speech. Hazelwood indicated that the school newspaper was a non-public forum, a designation that still carries with it a restriction against viewpoint discrimination. See Hazelwood, 484 U.S. at 268-70. However, under the Court's revisionist history, the nature of the forum appears to be irrelevant and schools may engage in content and viewpoint discrimination once sponsorship is demonstrated. See Muller v. Jefferson Lighthouse Sch., 98 F.3d 1530, 1542 (7th Cir. 1996) ("[A] school need not tolerate student expression of viewpoints which are fundamentally "inconsistent with its basic educational mission."' (quoting Hazelwood, 484 U.S. at 266)). But see Searcey v. Harris, 888 F.2d 1314, 1319 n.7 (11th Cir. 1989) ("Although the Supreme Court did not discuss viewpoint neutrality in Hazelwood, there is no indication that the Court intended to drastically rewrite First Amendment law to allow a school official to discriminate based upon a speaker's views ... . Hazelwood acknowledges a school's ability to discriminate based on content not viewpoint.").

145. See supra note 144. 
strict scrutiny, is not relevant to high school student organizations that fall within the scope of Hazelwood.

In adopting the attribution rationale, the Court assigns itself the task of determining whether or not the sponsorship of student clubs, either by providing access to school property or by providing funding, constitutes government speech. Again, the Court has set the scene for the doctrinal equivalent of an eighteen-car pileup. In both Rosenberger and Widmar, the Court regarded collegiate student groups as entities separate from the larger institution. The Court then conducted a forum analysis to determine the degree of constitutional scrutiny and inquired into the constitutionality of the content- and viewpoint-based nature of the institutional policies. In essence, it treated the speech of college student clubs as external speech within a limited public forum. If the attribution rationale is applied to Hazelwood, however, it appears that the opposite holds true in a high school environment: The speech of student groups is part of the speech of the school. As a result, the government, as speaker, may engage in both content- and viewpoint-based discrimination, and public forum doctrine is rendered almost irrelevant. ${ }^{146}$

In order to understand just how much is at stake for queer student groups in the relationship between the speech of clubs and the speech of schools, Gay Lesbian Bisexual Alliance v. Pryor ${ }^{147}$ is particularly instructive. In Pryor, the Eleventh Circuit held unconstitutional an Alabama statute that prohibited the recognition or funding of any collegiate student group that "fosters or promotes a lifestyle or actions prohibited by the sodomy and sexual misconduct laws."148 Relying upon Rosenberger, the appellate court held that a limited public forum existed for the funding of student groups and that the statutory regulation on gay student groups constituted impermissible viewpoint discrimination. ${ }^{199}$ Under Rosenberger's conception of Hazelwood, a similar holding protecting the rights of a high school queer student group to meet would be difficult under the attribution rationale, because the government is the speaker and is therefore permitted to engage in viewpoint discrimination. ${ }^{150}$

146. See supra note 125 and accompanying text.

147. 110 F.3d 1543 (11th Cir. 1997).

148. Id. at 1545 .

149. See id. at 1548-50; see also Gay and Lesbian Students Ass'n v. Gohn, 850 F.2d 361, 366-68 (8th Cir. 1988) (overturning university's denial of funding to gay student organization as impermissible content-based discrimination under Widmar); Gay Students Servs. v. Texas A\&M Univ., 737 F.2d 1317 (5th Cir. 1984) (overturning state university's refusal to recognize gay student organization).

150. Adding to the confusion, lower courts that have chosen to apply a forum analysis to the speech of high school student clubs implicitly ignore the attribution rationale. By using a forum analysis, those holdings suggest that organized student activities do not necessarily implicate 
If attribution alone is the only way to explain the constitutional importance of sponsorship, there is no principled reason to create constitutional distinctions, as the Court has done, between student groups in high schools and colleges. In both environments, the parent institution provides space to meet and funding for activities. Institutionally and organizationally, there is little difference. Yet, in the high school context, club sponsorship is considered governmental speech, while in the collegiate context it is not. ${ }^{151}$ This suggests that the doctrinal distinction between high school and college student organizations has nothing to do with questions of sponsorship, governmental speech, or the nature of public forums, but with the Court's beliefs about the respective missions of secondary and post-secondary education.

\section{Mergens: Maturity and Sponsorship}

One potential explanation for the Court's decision to treat high schools and colleges differently is an assumption that high school students (and, often, their parents) are not mature enough to understand that when a school "sponsors" a student club, it does not adopt the club's speech as its own or endorse the club's speech. This explanation, however, flies in the face of the Court's holding in Board of Education of Westside Community Schools v. Mergens. ${ }^{152}$ In Mergens, the Court upheld an excluded high school Christian club's right to meet under the Equal Access Act. ${ }^{153}$ While Mergens is not a constitutional free speech case, it recognized, in an Establishment Clause context, the ability of high school students to distinguish between school "endorsement" of religious speech and school toleration.

[F]ear of a mistaken inference of endorsement is largely selfimposed, because the school itself has control over any impressions it gives its students. To the extent a school makes clear that its recognition of respondents' proposed club is not an endorsement of the views of the club's participants, students will reasonably understand that the school's official recognition of the club evinces neutrality toward, rather than endorsement of, religious speech. ${ }^{154}$

By stating that high school students are mature enough to understand that the presence of a religious student organization does not

government speech when they occur on school property. If it were government speech, there would be no need for a forum analysis.

151. Indeed, the same question can be asked of public forum doctrine. If student groups are limited public forums at the college level, why not at the high school level?

152. 496 U.S. 226 (I990).

153. See id. at 253. Because the case was decided on statutory grounds, the Court declined to address the First Amendment free speech issue. See id.

154. Id. at 25 I (citation omitted). 
constitute "endorsement" for Establishment Clause purposes, Mergens casts further doubt upon the attribution rationale. If high school students are mature enough to understand that there is no "endorsement" under the First Amendment religion clauses, it is difficult to comprehend how they are not mature enough to understand lack of "sponsorship" for student organizations in a free speech context. Not only does this logic undermine Widmar's suggestion about the different maturity levels of high school and college students, ${ }^{155}$ but it demonstrates yet another difficulty in identifying a doctrinally consistent governing principle that governs Hazelwood's distinction between schoolsponsored and school-tolerated speech.

Thus far, I have argued that Hazelwood's focus on school sponsorship to determine constitutional protection is without merit. In the next Part, I argue that the Court should return to a mission-based paradigm for student speech and that it has implicitly followed this approach all along.

VI

\section{Adoption of a Mission-Based Rationale}

To rehabilitate First Amendment doctrine in secondary schools, the Court should abandon its current focus on school sponsorship and public forum doctrine. Instead, the Court should return to the course it adopted in Tinker, Pico, and Fraser; that is, it should conduct an inquiry into the institutional mission of the school and scrutinize the relationship between the mission and the regulation on speech. In essence, this proposal adopts a similar approach to the one used in the Court's rights-based jurisprudence. The "governmental interest" is the pursuit of an organizational mission, and the "tailoring" is the relation between the mission and the contested regulation on speech. In adopting this revised focus, however, the Court should view the mission of American education not as an absolute dichotomy between value inculcation and the fostering of an independent mind, but as a continuum, recognizing that educational institutions often pursue both goals simultaneously.

In looking to the mission, courts should recognize that the ultimate value of speech is not in its relation to doctrinally inconsistent concerns related to property or attribution. Rather, its value derives from the way that freedom of speech helps or hinders our social commitment to public education. Implicit in this argument is a belief that the ultimate value of free speech depends upon the social and organizational context of the speech, rather than amorphous commitments to selfgovernance or a marketplace of ideas. ${ }^{156}$ Consider, for example, speech

155. See supra notes 138-139 and accompanying text.

156. See Post, Recuperating First Amendment Doctrine, supra note 19, at 1276-77 ("Instead of 
on a military base. The government maintains wide latitude to regulate speech by military personnel based upon security and discipline concerns that directly relate to the organizational mission. ${ }^{157}$ This includes speech that, in another social or organizational context, might be entitled to constitutional protection against state regulation.

When one considers the value of speech in the American high school, First Amendment jurisprudence should reflect the competing institutional concerns. On one hand, we want schools to perform their assigned mission free from the constricting effects of judicial review. Public schools exist, at least in part, to disseminate information and civic values determined by the political communities attached to the school. To fulfill that mission, schools must maintain some authority to constrain discourse that competes with or potentially dilutes the communicative product of this educational mission. Otherwise, it would be impossible for schools to function, with pedagogical concerns giving way to adolescent cacophony.

At the same time, free speech assumes a distinctive and unique importance in an educational context, protecting both institutional and extra-institutional values for three reasons. First, schools exist as miniature communities within a larger sociopolitical community that has codified its values of pluralism and open political discourse into law. As part of their role to prepare students for civic engagement, schools have an institutional interest in promoting free speech in order to inculcate these larger social values. Second, schools have an interest in equipping students with the critical thinking skills necessary to participate as social and political beings in a marketplace of ideas and identities. This interest is particularly important in the American high school, given the formative role of adolescence in the psychological development of individual identity. ${ }^{158}$ If our teenage years play an important role in who we become as adults, exposure to a wide range of ideas during these years is essential to an individual's civic evolution. Third, schools have an interest in promoting a process of selfrealization for its own sake, above and beyond enabling individual participation in a larger political process. The very notion of individual liberty suggests that there is an inherent value in the search for selftruth, both as a necessary predicate for a larger process of collective

aspiring to articulate abstract characteristics of speech, doctrine ought to identify discrete forms of social order that are imbued with constitutional value, and it ought to clarify and safcguard the ways in which speech facilitates that constitutional value.").

157. See Brown v. Glines, 444 U.S. 348, 354 (1980); Post, Between Governance and Management, supra note 19, at 1770-71.

158. See Erik Erikson, Childhood and Society 261-63 (2d ed. 1963). 
realization and as part of a utilitarian notion of maximizing individual happiness. ${ }^{159}$

A mission-based test would focus the Court's attention, not on irrelevant proprietary or attribution concerns, but squarely on the crux of the matter-the reconciliation of conflicting institutional objectives that affect the appropriate role of free speech in an educational environment. In fact, this focus on the institutional mission is precisely the approach the Court has already adopted once the sponsorship rhetoric is stripped away. Witness the Court's underlying preoccupation with the mission of American education in Tinker and Hazelwood. The Tinker Court arrived at its holding after identifying the mission of the school and determining whether or not the students' Vietnam War protest affected the mission. The "Tinker test" is specifically designed to extend constitutional protection only to the point that the speech substantially affects the institution's pedagogical imperatives. Likewise, in Hazelwood, the Court's holding reflects a concern that unlimited journalistic discretion would severely harm the school's mission of value inculcation identified in Fraser and Pico. ${ }^{160}$ Hazelwood's crucial error was not in protecting the school's right to engage in value inculcation free from judicial scrutiny. Instead, the Court erred by viewing value inculcation as the sole mission of secondary schools and by promulgating a constitutional test that did not demand any meaningful relationship between the mission and the regulation on speech.

Under a mission-based lens, the distinctions between the rules applied by Tinker and Hazelwood begin to blur. The difference is not the use of public forum doctrine or whether the speech is school sponsored. Instead, the cases are merely a continuation of the Court's earlier reevaluation of the mission of American education combined with a shift in the degree of judicial restraint necessary to allow schools to accomplish that mission. Differing conceptions of the mission of education also underlie the comparatively heightened scrutiny the Court applied to post-secondary environments in Widmar ${ }^{161}$ and Rosenberger. ${ }^{162}$

Thus, the proper constitutional questions-even under existing doctrine-are the mission of the institution, the relationship between the mission and the regulation on speech, and the circumstances under

159. See generally Martin H. Redish, The Value of Free Speech, 130 U. PA. L. REv. 591 (1982).

160. See Hazelwood, 484 U.S. at 272 (envisioning the role of schools as "a principal instrument in awakening the child to cultural values, in preparing him for later professional training, and in helping him to adjust normally to his environment" (quoting Brown v. Board of Educ., 347 U.S. 483, 493 (1954))).

161. See Widmar, 454 U.S. at 267 n.5 ("The college classroom with its surrounding environs is peculiarly the marketplace of ideas." (quoting Healy v. James, 408 U.S. 169, 180 (1972))).

162. See Rosenberger, 515 U.S. at 835 (discussing the importance of protecting First Amendment principles in "the University setting, where the State acts against a background of tradition and thought and experiment that is at the center of our intellectual and philosophic tradition"). 
which the Court defers to school authorities in seeking to carry out that mission by regulating speech. Because of the competing missions present in an educational context, resolution of these constitutional questions places heightened demands on courts reviewing the constitutionality of speech regulations of high school student clubs.

VII

ApPLying the Mission Test to Student Groups

\section{A. What Is the Mission?}

By adopting a bipolar paradigm for identifying the institutional mission, the Supreme Court has skewed the constitutional analysis to the point that it no longer adequately addresses the real organizational and pedagogical issues presented by the American educational system. Instead of recognizing that most schools adopt a dual pedagogical mission-the inculcation of values and the fostering of an independent mind-the Court has implied that the mission must be either one or the other.

The Court should instead view the mission of American education as a continuum, with value inculcation on one side and the fostering of an independent mind on the other. Some school activities advance the value inculcation mission by communicating a defined body of information. These activities generally, but not always, include invited speakers, schoolwide assemblies, and most curriculum-related activities. Because value inculcation is part of a school's mission, courts should subject institutional regulation in these contexts to minimal judicial scrutiny in order for the school to achieve this objective.

There are other school activities, however, for which the goal is not to codify or communicate values or information, but to encourage students to explore their independent identity and to define their own interests or passions. Student clubs serve precisely these purposes. They present an opportunity for students to explore interests or identities, as a stamp collector, a scuba diver, a Republican, a Muslim, an African American, or a lesbian. Far from the school dictating a code of fixed conduct, the objectives and areas of focus for each club are defined by the students. Attempting to place student clubs within the same mission as value-inculcating activities provides for constitutional convenience, but it does not accurately reflect the complexity of American education, the diverse pedagogical objectives contained within the school environment, and the need for First Amendment protection to allow students to accomplish some of those objectives.

A federal district court used similar mission-based logic to uphold the constitutional rights of students to distribute a non-schoolsponsored religious newspaper on school grounds in Rivera v. East Otero 
School District R-1:163 "High school students ... must develop the ability to understand and comment on the society in which they live and to develop their own sets of values and beliefs .... [I]nhibitions on individual development defeat the very purpose of education in secondary schools." $" 164$

Furthermore, this mission-based approach finds some doctrinal basis in the concept of the limited public forum. Under that doctrine, the Court has recognized that institutions are capable of creating, intentionally or otherwise, environments that exist to promote free expression. Consequently, their ability to regulate speech in these environments is limited. Unlike public forum doctrine, however, the mission-based test relies upon the larger institutional objectives of schools and the value of speech in relation to those objectives, rather than the stated policy and practice of the school in the particular forum or a distinction between content and viewpoint discrimination.

\section{B. When Is It Appropriate for Courts to Interfere?}

Student clubs exist at an awkward point between institutional commitments to promote the exploration of individual identity and to reinforce often hostile community values. ${ }^{165}$ Schools seeking to regulate the clubs' speech will undoubtedly argue that the regulation exists to further the schools' mission of value inculcation. As a result, under a mission-based test, the constitutional issue hinges upon the degree to which courts are willing to place the school's own conception of its mission under scrutiny.

Should courts take schools at their word? This question requires a case-by-case inquiry, dependent upon (I) the extent to which the school has delineated the specific information or values that it wants to communicate, and (2) the degree to which the school's actions create the objective impression that the transmission of values or information is

163. 721 F. Supp. 1189 (D. Colo. 1989).

164. Id. at 1194.

165. It is worth noting that several states have responded to issues related to queer youth in more positive ways. Some have adopted statutes that prohibit sexual orientation discrimination in their schools. See, e.g., Mass. Gen. Laws ANN. ch. 71, $\$ 89$ (West 1996); Minn. Stat. ANn. $§ 363.12$ (West 1996); 22 PA. Code $\$ 5.4$ (1996); Vt. Stat. ANN. tit. $16, \$ 565$ as defined in VT. Stat. ANN. tit. 16, \$11(a)(26) (West 1995); WIs. Stat. ANN. $\$ 118.13$ (West 1996). Passage of this legislation has ushered in a new era of queer activism with high school students playing an active role in lobbying lcgislators. See Sara Rimer, Gay Rights Law for Schools Advances in Massachusetts, N.Y. Times, Dec. 8, 1993, at A18. A recent Seventh Circuit case, Nabozny v. Podlesny, 92 F.3d 446 (7th Cir. 1996), demonstrates how much is potentially at stake for school districts that fail to adopt inclusive policies. Jamie Nabozny's classmates subjected him to repeated anti-gay harassment. See $i d$. at 451 . When the school district took no remedial action, Nabozny filed a lawsuit. See id. at 451 52. After the appellate court held that Nabozny had a cognizable claim, the school district settled out of court for $\$ 900,000$. See $\$ 900,000$ Won By Gay Man in Abuse Case, N.Y. Times, Nov. 21, 1996, at B11. 
the purpose of the activity. Consider the free speech rights of a student in math class. The existence of a geometry textbook and a stateauthorized class curriculum suggests that the school is communicating specific knowledge about geometry. Furthermore, schools allocate the bulk of classroom instructional time to the transmission and discussion of this fixed body of information. As a result, a regulation on student speech in math class should receive minimal judicial scrutiny unless that regulation extends beyond what is needed to allow the school to transmit the information.

With student clubs, the scenario is very different. As self-governing units, the clubs are only rarely designed as vehicles for schools to convey specific information or values. Furthermore, the existence of multiple clubs that range across a wide spectrum of interests and ideological perspectives indicates that the inculcation of specific values is not the objective furthered by student club activities. As a result, courts should consider student clubs as part of the school's mission to encourage exploration of independent interests and identities and hold regulations on most student groups, including queer student groups, unconstitutional because the regulations do not advance the mission.

\section{Queer Student Clubs Under Hazelwood}

Even if one accepts Hazelwood's premise that schools have one uniform mission, queer student organizations are no more threatening to that uniform mission of value inculcation than any other student group. The presence of a queer student group does not imply that the school "approves" of a particular sexual orientation as part of its desired value system any more than it adopts or endorses the ideological agenda of the Young Republicans. ${ }^{166}$ Courts should not grant constitutional camouflage for schools to create empty distinctions between queer student groups and other clubs whose purpose is to provide students with a sense of racial, gender, or ethnic identity. Like the Latino Students Union or the Irish Heritage Club, queer student groups provide their members with a sense of history and cultural identity, along with an atmosphere of support in an often hostile high school environment.

Furthermore, when one considers the cumulative effects of club bans, it is difficult to understand how the rcgulation of queer clubs serves the "legitimate pedagogical objective" of value inculcation. Rather than sending a message condemning the discussion of human sexuality, state

166. See Widmar, 454 U.S. at 274 ("[A]n open forum in a public university does not confer any

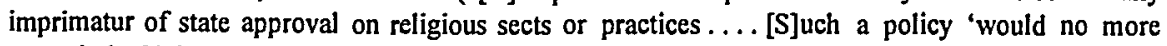
commit the University ... to religious goals' than it is 'now committed to the goals of the Students for a Democratic Society, the Young Socialist Alliance,' or any other group eligible to use its facilitics." (quoting Chess v. Widmar, 635 F.2d 1310, 1317 (1980))). 
statutes like the one passed in Utah impair the educational, psychological, and social development of queer teens. While bans at the elementary and junior high school level may be age appropriate, there is every indication that high school students can and do ponder questions related to human sexuality on a deeply personal level. ${ }^{167} \mathrm{~A}$ majority of gays and lesbians report experiencing same-sex attraction and arousal before the age of sixteen. ${ }^{168}$

The school's pedagogical imperatives become more dubious when one considers the vulnerable nature of the population in question. ${ }^{169}$ Gay and lesbian youth are significantly more likely to attempt suicide than their straight counterparts. ${ }^{170}$ The failure of educational institutions to provide a supportive environment is among the factors that place queer youth at such tremendous social risk. ${ }^{171}$

\section{High School Hate Groups}

One potential by-product of a mission-based test is the extension of First Amendment protections to a hypothetical Nazi student group or the non-hypothetical Students Against Faggots Everywhere. If part of the mission of public schools is to foster a student's independent consciousness, why should that mission not extend to a student who wishes to explore his identity as a Klan member or a homophobe?

Indeed, at least one federal district court has already adopted this position in a high school context. In Pyle v. South Hadley School Committee, ${ }^{172}$ two sons of a constitutional law professor challenged their high school's dress code provisions, which banned clothing that (1) contained lewd or vulgar comments, (2) harassed or demeaned others based upon their sex, color, sexual orientation, or membership in other protected groups, or (3) advertised alcoholic beverages, tobacco, or drugs. ${ }^{173}$

167. See generally AARON FRICKe, Reflections of A Rock LobSter: A StORY AbOUT GROWING UP GAY (1981).

168. See Dennis A. Anderson, Lesbian and Gay Adolescents: Social and Developmental Considerations, in The Gay Teen: Educational Practice and Theory for Lesbian, Gay and BISEXUAL AdOLESCENTS, supra note 3, at 17-18.

169. See Amy Lovell, "Other Students Always Used to Say, 'Look at the Dykes'": Protecting Students from Peer Sexual Orientation Harassment, 86 CALIF. L. REv. 617, 623-28 (1998).

170. See Blumenfeld, supra note 3, at 217 ("The earlier a young person is aware of same-sex attractions, the greater the problems they face and the more likely they are to develop suicidal feelings and behaviors."); Paul Gibson, Gay Male and Lesbian Youth Suicide, in U.S. DEP'T OF Health and Human Services, Report of the Secretary's Task Force on Youth Suicide 3-110 (Marcia R. Feinleib ed., 1989) (stating that lesbian and gay youth are two to three times more likely to attempt suicide and that those suicides may constitute 30 percent of all completed youth suicides). But see Lovell, supra note 169, at 626 n. 48 (giving overview of critiques of Gibson's methodology).

171. See Gibson, supra note 170 , at 3-128.

172. 861 F. Supp. 157 (D. Mass. 1994).

173. See id. at 163 . 
Over the course of a year, the brothers arrived at school dressed in a number of different $\mathrm{T}$-shirts, bearing legends ranging from "Coed Naked Band; Do it to the Rhythm," and a depiction of two male soldiers kissing along with the inscription "Read My Lips," to a homemade "Coed Naked Censorship-They do it in South Hadley" T-shirt. ${ }^{174}$

The Pyle court upheld the school's "vulgar and lewd" provision under Fraser but declared the "harassment" provision unconstitutional as impermissible viewpoint discrimination. ${ }^{175}$ While the T-shirt of the two men kissing might be permissible (if not found to be vulgar or lewd), "[a] T-shirt carrying a depiction objecting to homosexuality, on the other hand, would be flatly forbidden by the code."176

An in-depth discussion of the constitutionality of hate speech provisions, as well as the applicability of R.A.V. v. City of St. Paul ${ }^{177}$ to public schools, is beyond the scope of this Comment. I would suggest, however, that under a mission-based test, schools could potentially regulate these groups within constitutional boundaries because their presence detracts from the school's mission to promote the independent exploration of interests and identities. High school hate groups, unlike queer student groups, exist almost solely to prevent others from engaging in self-expression. If the purpose behind allowing student groups is to assist students in defining their interests or identities, the First Amendment should protect this interest. Because the existence of hate groups aetively prevents schools from advancing this mission, regulation of hate groups is needed to enable the school to further organizational objectives.

In making this argument, I distinguish the mission advanced by student clubs from the mission Professor Robert Post refers to as "democratic education"178 or "critical education." "Democratic education" sees the "purpose of public education to be the creation of autonomous citizens, capable of fully participating in the rough and tumble world of public discourse"; 180 "critieal education" prioritizes education's role in the discovery of truth, which requires an unfettered exchange of ideas. ${ }^{181}$ Both of these notions envision the educational mission in terms of its benefit to the larger society, whether as a training ground for the political process or as part of a larger seareh for

174. See id. at 161-63.

175. See id. at 170-73.

176. Id. at 172 .

177. 505 U.S. 377 (1992) (declaring city hate speech ordinance unconstitutional as impermissible viewpoint discrimination).

178. Post, Racist Speech, supra note 19, at 321.

179. Id. at 322 .

180. Id. at 321 .

181. See id. at 322 . 
truth. As a result, Professor Post argues that constitutional protection extends to hate speech, since the speech acts to further the institutional mission. ${ }^{182}$

By viewing the value of self-realization exclusively as a means to achieve larger goals, however, Professor Post's classifications ignore the value of self-realization as an end in itself. By relying upon rhetoric of fear and intimidation, hate speech directly inhibits the search for self-truth. If, as I briefly argued earlier, ${ }^{183}$ the process of self-realization has an inherent value, and if hate speech inhibits that process, then some regulation of hate speech is appropriate to protect First Amendment values of self-realization in an educational context.

The argument to deprive student hate groups of First Amendment protection has a number of obvious and potentially fatal problems. If the basis for distinguishing the self-expression of gay students from the expression of Nazi students is that the latter's rhetoric is designed to quash the self-expression of others, could a fundamentalist Christian student organization not offer the same critique of a gay/straight alliance? In response, one could attempt to distinguish between speech and action, protecting the speech rights of hate groups only up until the point that it results in disruptive actions targeted at other students. Alternatively, one could condition constitutional protection based upon the group's own conception of its objectives, creating a distinction between a hypothetical Straight Alliance and Students Against Faggots Everywhere based upon the degree to which their stated mission challenges the self-expression of others. If, however, a basic distinction between hate groups and queer student clubs is untenable, Tinker's "material or substantial disruption" test should provide an adequate safeguard to ensure that hate group activity does not significantly intrude on the rights of other students. ${ }^{184}$

\section{CONCLUSION}

As gay and lesbian youth become more vocal and visible throughout American society, both inside and outside our schools, high school administrators and school district officials will be faced not only with new challenges, but with an opportunity to address the overwhelming needs of a long silent and underserved segment of the school population. High schools, like other institutions, must reckon with the increased recognition of sexual diversity within modern life.

182. See id. at $322-24$.

183. See supra text accompanying note 159 .

184. See Phillips v. Anderson County Sch. Dist. Five, 987 F. Supp. 488 (D.S.C. 1997) (applying Tinker test to find that school did not violate student's First Amendment rights by requiring student to refrain from wearing a jacket made to look like a Confederate flag). 
Apart from policy concerns, queer student organizations will present courts with the opportunity to reevaluate their approach to First Amendment doctrine, in terms of school speech, the forum-based approach, and questions of sponsorship. Adoption of a mission-based continuum model would not only address the underlying doctrinal concerns and provide a more solid foundation for categorical First Amendment analysis, but would more accurately reflect the complex organizational structure and pedagogical objectives of the American high school. 